Jurnal PG-PAUD Trunojoyo : Jurnal Pendidikan dan Pembelajaran Anak Usia Dini, Volume 6, Nomor 2, Oktober 2019, hal 63-69, ISSN : 2528-3553 (online), ISSN: 2407-4454 (print)

\title{
ANALISIS KESIAPAN GURU DALAM MENGIMPLEMENTASIKAN KURIKULUM 2013 DI PAUD
}

\author{
Melania Marsela Kongen \\ Petrus Redy Partus Jaya \\ Program Studi Pendidikan Guru Pendidikan Anak Usia Dini Unika Santu Paulus Ruteng \\ Email: melaniakongen31.01@gmail.com,petrusredypartusjaya@gmail.com
}

Received (Bulan Mei 2019), Accepted (Bulan Agustus 2019), Published (Bulan Oktober 2019)

\begin{abstract}
This study was conducted to determine the extent of teacher readiness in implementing the 2013 Curriculum in PAUD. This type of research was a descriptive study with a qualitative approach. The research subjects were 21 teachers in Langke Rembong sub-district. Data collection techniques using interviews and questionnaires. The instrument used was interview guidelines and questionnaire items in the form of open questions. In this study, researchers examined the readiness of teachers related to the implementation of the 2013 Curriculum (K'13) in terms of Curriculum Structure, Guidelines for Detection of Children Growth, Learning Guidelines, Assessment Guidelines, and Educator Guidebooks. Teacher readiness is measured by the extent of the teacher's ability to implement the 2013 Curriculum in PAUD. Based on the findings related to five things in organizing the 2013 Curriculum in PAUD, it appears that administratively PAUD teachers are ready to implement the 2013 Curriculum in PAUD. However, practically the teachers still experience difficulties. These difficulties are related to the application of a scientific approach and the implementation of authentic assessments. In learning, teachers have difficulty designing activity themes and materials that encourage children to observe, ask questions, gather information, reason, and communicate. That is why, learning is more directed at drawing and coloring activities. In doing the assessment, the teacher has difficulty compiling data on the results of the daily assessment and compiling reports on child development. This difficulty occurs because most of the teachers are high school / vocational high school and non-PAUD undergraduate students.
\end{abstract}

Keywords: Teacher Readiness, 2013 Curriculum, PAUD.

\begin{abstract}
Abstrak: Penelitian ini dilakukan untuk mengetahui sejauh mana kesiapan guru dalam mengimplementasikan Kurikulum 2013 di PAUD. Jenis penelitian yang digunakan adalah penelitian deskriptif dengan pendekatan kualitatif. Subjek penelitian berjumlah 21 orang guru yang ada di kecamatan Langke Rembong. Teknik pengumpulan data menggunakan wawancara dan angket. Instrumen yang digunakan adalah pedoman wawancara dan item angket dalam bentuk pertanyaan terbuka. Dalam penelitian ini, peneliti mengkaji kesiapan guru terkait implementasi Kurikulum 2013 (K'13) dalam hal Struktur Kurikulum, Pedoman Deteksi DIni Tumbuh Kembang Anak, Pedoman Pembelajaran, Pedoman Penilaian, dan Buku-buku Panduan Pendidik. Kesiapan guru diukur dari sejauh mana kemampuan guru mengimplementasikan Kurikulum 2013 di PAUD. Berdasarkan temuan terkait lima hal dalam penyelenggaraan Kurikulum 2013 di PAUD tampak bahwa secara administratif para guru PAUD sudah siap melaksanakan Kurikulum 2013 di PAUD. Namun, secara praktis para guru masih mengalami kesulitan. Kesulitan tersebut terkait dengan penerapan pendekatan saintifik dan pelaksanaan penilaian otentik. Dalam pembelajaran, para guru kesulitan merancang tema dan materi kegiatan yang mendorong anak melakukan kegiatan mengamati, menanya, mengumpulkan informasi, menalar, dan mengkomunikasikan. Itu sebabnya, pembelajaran lebih banyak diarahkan pada kegiatan menggambar dan mewarnai. Dalam melakukan penilaian, guru kesulitan melakukan kompilasi data hasil penilaian harian dan menyusun laporan perkembangan anak. Kesulitan ini terjadi karena sebagian besar guru berkualifikasi SMA/SMK dan S-1 non PAUD.
\end{abstract}

Kata Kunci : Kesiapan Guru, Kurikulum 2013, PAUD.

\section{PENDAHULUAN}

Kurikulum pendidikan merupakan komponen yang sangat penting dalam penyelenggaraan pendidikan. Dikatakan penting karena kurikulum merupakan pedoman yang menentukan arah dan tujuan pendidikan. Peran penting kurikulum pendidikan mengharuskan pemerhati pendidikan untuk terus mengkaji relevansi kurikulum dengan perkembangan dan perubahan kehidupan masyarakat dari waktu ke waktu.

Pada konteks kehidupan masyarakat Indonesia di era global saat ini yang dicirikan dengan persoalan degredasi moral, intoleran, dan sparatis menuntut respon banyak pihak untuk mencari strategi dan solusi yang tepat. Dalam dunia pendidikan, strategi dan solusi 
64 Jurnal PG-PAUD Trunojoyo : Jurnal Pendidikan dan Pembelajaran Anak Usia Dini, Volume 6, Nomor 2, Oktober 2019, hal 63-69, ISSN : 2528-3553 (online), ISSN: 2407-4454 (print)

dapat dilakukan melalui desain kurikulum yang jelas, operasional, dan terukur. Pada tataran ini, Kurikulum 2013 didesain untuk menjawabi tantangan dan persoalan kehidupan berbangsa dan bernegara Indonesia.

Salah satu unsur fundamental dalam Kurikulum 2013 adalah pendidikan karakter terutama pada tingkat dasar, yang akan menjadi fondasi bagi tingkat berikutnya. Revitalisasi dan penekanan karakter dalam pengembangan Kurikulum 2013 diharapkan dapat menyiapkan sumber daya manusia yang berkualitas, sehingga masyarakat mampu menghadapi berbagai masalah ataupun tantangan di era global saat ini.

Aktor kunci dalam pelaksanaan kurikulum adalah guru. Dalam konteks kurikulum, guru memiliki beberapa peran, seperti perancang kurikulum, pengembang kurikulum, pelaksana kurikulum, dan pengevaluasi kurikulum. Pada tataran peran guru dalam kurikulum pendidikan, guru dituntut untuk mempunyai kompetensi baik kompetensi pedagogik, keribadian, sosial, maupun profesional. Kompetensi yang dimiliki oleh guru menjadi tanda sekaligus prasyarat kesiapan guru dalam mengimplentasikan Kurikulum 2018.

Realitas penyelenggaraan pendidikan terutama PAUD formal di Kecamatan Langke Rembong Kabupaten Manggarai menunjukkan bahwa penambahan jumlah lembaga PAUD dari tahun ke tahun berbanding terbalik dengan peningkatan mutu penyelenggaraannya. Data membuktikan bahwa pada tahun 2018 di Kecamatan Langke Rembong terdapat 32 PAUD (Kelompok Bermain dan Taman Kanak-kanak). Angka 32 dikategorikan banyak untuk konteks kecamatan yang ada di pusat kabupaten. Yang menarik bahwa tenaga pendidik yang berkualifikasi PAUD hanya sebesar $8,24 \%$. Ketersediaan tenaga pendidik seperti ini berbanding lurus dengan tingkat ketersediaan dokumen kurikulum (de Gomes, Rahmat, dan Palmin, 2018).

Kondisi penyelenggaraan PAUD seperti ini memotivasi peneliti untuk mengkaji lebih mendalam tentang kesiapan guru PAUD di Kecamatan Langke Rembong dalam mengimplemtasi kurikulum 2013 PAUD. Penelitian ini bertujuan menganalisis kesiapan guru PAUD di Kecamatan Langke Rembong dalam Mengimplementasi Kurikulum 2013. Urgensitas penelitian ini adalah adanya praktik penyelenggaraan PAUD yang berjalan di luar rel kurikulum. Hasil kajian ini diharapkan mampu memetakan kesiapan guru PAUD di Kecamatan Langke rembong dalam mengimplemtasi Kurikulum 2013.

Perubahan suatu kurikulum merupakan suatu hal yang biasa demi memperbaiki kualitas pendidikan suatu Negara. Sama halnya, untuk meningkatkan kualitas pendidikan nasional, salah satunya dilakukan dengan evaluasi dan memperbaharui kurikulum pendidikan nasional. Reformasi suatu kurikulum bertujuan agar peserta didik menjadi cerdas, bermoral, berakhlak, kreatif, komunikatif, dan toleran dalam kehidupan keberagaman.

Perubahan Kurikulum KTSP 2006 ke Kurikulum 2013 merupakan salah satu upaya untuk memperbaharui setelah dilakukan evaluasi kurikulum sesuai dengan kebutuhan anak bangsa atau generasi muda. Inti dari Kurikulum 2013 terletak pada upaya penyederhanaan dan sifatnya yang tematikintegratif. Seperti diungkapkan Alma, dkk. (2013) bahwa Kurikulum 2013 disiapkan untuk mencetak generasi yang siap di dalam menghadapi tantangan masa depan. Karena itu, kurikulum disusun untuk mengantisipasi perkembangan masa depan. Titik berat Kurikulum 2013 adalah bertujuan agar peserta didik atau siswa memiliki kemampuan yang lebih baik dalam melakukan observasi, bertanya (wawancara), bernalar, dan mengomunikasikan (mempresentasikan) apa yang diperoleh atau diketahui setelah menerima materi pembelajaran.

Setidaknya ada dua argumentasi pokok atas perlunya perubahan kurikulum 2006 (KTSP) menjadi Kurikulum 2013, yakni: pertama, internal, di antaranya: (a) konten kurikulum yang masih terlalu padat; (b) belum sepenuhnya berbasis kompetensi sesuai dengan tuntutan fungsi dan tujuan pendidikan nasional; (c) kompetensi belum menggambarkan secara holistik domain sikap, keterampilan, dan pengetahuan; (d) belum peka dan tanggap terhadap perubahan social yang terjadi pada tingkat lokal, nasional, dan global; (e) standar proses pembelajaran belum menggambarkan urutan pembelajaran yang rinci sehingga membukpeluang penafsiran yang beraneka ragam dan berujung pada pembelajaran yang berpusat pada guru; (f) standar penilaian belum mengarahkan pada penilaian berbasis kompetensi (proses an hasil) 
Jurnal PG-PAUD Trunojoyo : Jurnal Pendidikan dan Pembelajaran Anak Usia Dini, Volume 6, Nomor 2, Oktober 2019, hal 63-69, ISSN : 2528-3553 (online), ISSN: 2407-4454 (print)

dan belum secara tegas menuntut adanya remediasi secara berkala; dan (g) dengan KTSP memerlukan dokumen kurikulum yang lebih rinci agar tidak menimbulkan muti tafsir. Kedua, eksternal, arus globalisasi dan perkembangan pendidikan pada tingkat internasional. Arus globalisasi akan menggeser pola hidup masyarakat dari agraris dan perniagaan tradisional menjadi masyarakat industry dan perdagangan modern. Seperti terlihat dari munculnya blog-blog organisasi perdagangan dunia, antara lain: World Trade Organization (WTO), ASEAN Community MEA-2015, Asia Pacific Economic Cooperation (APEC), North American Free Trade Association (NAFTA), dan Asean Free Trade Area (AFTA).

Berbagai permasalahan internal dan eksternal berbangsa di era globalisasi dan sebagai upaya persiapan anak didik dan generasi muda yang mampu hidup pada zamannya, membutuhkan Kurikulum 2013 yang memberi solusi terhadap berbagai tantangan masa depan. Di sisi lain beragam tantangan masa depan tersebut membutuhkan beragam, kompetensi masa depan, berupa kemampuan berkomunikasi, kemampuan berpikir jernih dan kritis, kemampuan mempertimbangkan segi moral suatu permasalahan, kemampuan warga Negara yang efektif, kemampuan mencoba untuk mengerti dan toleran terhadap pandangan yang berbeda, kemampuan hidup dalam masyarakat yang global, kemampuan minat luas tentang hidup, memiliki kesiapan untuk bekerja dan kecerdasan sesuai bakat dan minat.

Dari berbagai permasalahan dan kelemahan Kurikulum KTSP 2006 di atas, maka sejumlah perubahan yang ada dalam Kurikulum 2013 adalah: (1) Perubahan Standar Kompetensi Lulusan. Memerhatikan pengembangan nilai, pengetahuan, dan keterampilan secara terpadu dengan fokus pada pencapaian kompetensi; (2) Perubahan Standar Isi. Memfokuskan pada kompetensi yang dikembangkan menjadi mata pelajaran melalui pendekatan tematikintegratif; (3) Perubahan Standar Proses. Guru wajib merancang dan mengelola proses pembelajaran aktif yang menyenangkan. Peserta didik difasilitasi untuk mengamati, menanya, mengolah, menyajikan, menyimpulkan, dan mencipta; (4) Perubahan Standar Evaluasi. Penilaian yang mengukur penilaian autentik yang mengukur kompetensi sikap, keterampilan, serta pengetahuan berdasarkan hasil dan proses. Sebelumnya, penilaian hanya mengukur kompetensi.

Berkaitan dengan peran guru dalam kurikulum, ia memiliki peranan penting yaitu sebagai aktor yang mengembangkan atau sebagai pengembang kurikulum. Salah satu permasalahan atau hambatan dalam mengimplementasikan kurikulum baru adalah proses sosialisasi yang belum merata dan belum mengenai sasaran yang tepat seperti para guru, siswa, semua personil sekolah, masyarakat, dan orang tua di berbagai daerah dan pelosok daerah. Tetapi, guru adalah aktor yang terlibat langsung atau yang menjalani proses pembelajaran sehingga sosialisasi harus dilakukan secara berkala dan merata bagi semua guru.

Keberhasilan dari suatu kurikulum yang ingin dicapai sangat bergantung pada faktor kemampuan yang dimiliki oleh setiap guru (Uno, 2009). Hal ini dapat diumpakan seperti ini. Jika seorang guru memiliki kemampuan yang baik dalam hal ini mempunyai kemampuan yang tinggi dalam hal menyerap informasi, maka pasti guru itu akan mudah beradaptasi dan menerapkan apa yang sudah dia peroleh. Apalagi jika guru tersebut didukung dengan empat kompetensi pendidik yang dihayatinya dengan baik serta kualifikasi pendidikan atau latar belakang pendidikannya sesuai dengan pekerjannya sekarang. Tetapi, jika seorang guru memiliki kemampuan dalam hal menyerap informasi agak lemah atau rendah karena tidak didukung dengan empat kompetensi atau kualifikasi pendidikannya maka pasti dalam implementasi kurikulum akan terhambat. Jadi, dalam hal ini guru harus memiliki pengetahuan dan tanggungjawab berkenaan dengan kurikulum dan bagaimana cara mengembangkan kurikulum tersebut. Karena menurut Nasution (2008), guru adalah pelaksana langsung dari kurikulum di suatu kelas, gurulah yang bertugas mengembangkan kurikulum pada tingkat pembelajaran, gurulah yang langsung menghadapi berbagai permasalahan yang muncul sehubungan dengan pelaksanaan kurikulum di kelas, dan tugas gurulah yang mencarikan upaya memecahkan segala permasalahan yang dihadapi dan melaksanakan upaya itu

Upaya memperbaiki suatu kurikulum perlu diketahui kompetensi guru sebagai 
66 Jurnal PG-PAUD Trunojoyo : Jurnal Pendidikan dan Pembelajaran Anak Usia Dini, Volume 6, Nomor 2, Oktober 2019, hal 63-69, ISSN : 2528-3553 (online), ISSN: 2407-4454 (print)

partisipan yang merupakan aktor dalam pengembangannya, pengetahuan para guru mengenai seluk beluk kurikulum, serta yang paling penting adalah kemampuan membuat perencanaan (Hamalik, 2008). Motivasi kerja guru dalam mengembangkan kurikulum di sekolah akan berdayaguna, apabila guru memiliki keinginan, minat, penghargaan, sikap bertanggung jawab dan meningkatkan dirinya dalam upaya mengembangkan kurikulum (Agung, 2010). Usaha perubahan kurikulum tersebut sebaiknya perlu melakukan penyelidikan mengenai sikap dan reaksi guru. Hal tersebut penting karena keberhasilan perubahan bergantung pada kesesuaian nilai- nilai guru dan partisipasi guru dalam perubahan tersebut. Guru dituntut untuk selalu mencari gagasan baru dalam penyempurnaan praktik pembelajaran dan pelaksanaan kurikulum.

Kunci sukses keberhasilan implementasi kurikulum 2013 adalah kreativitas guru, karena guru merupakan faktor penting yang besar pengaruhnya, bahkan sangat menentukan berhasil atau tidaknya peserta didik dalam belajar. Kurikulum 2013 dalam implementasinya memang agak sulit dilaksanakan di berbagai daerah karena sebagian besar guru belum siap. Ketidaksiapan guru ini, hanya terkait dengan kompetensinya tetapi juga masalah kreativitasnya, yang disebabkan oleh rumusan kurikulum yang lambat disosialisasikan oleh pemerintah. Dalam hal ini, guru-guru yang bertugas di daerah dan di pedalaman akan sulit mengikuti hal-hal baru dalam waktu singkat, apalagi kurikulum 2013 menggunakan pendekatan tematik integratif yang memerlukan waktu yang cukup untuk memahami dan merealisasikannya.

Tugas guru tidak hanya menyampaikan informasi kepada peserta didik, tetapi juga harus kreatif memberikan layanan dan kemudahan untuk belajar (facilitate learning) bagi seluruh peserta didik, agar mereka dapat belajar dengan suasana yang menyenangkan, gembira, penuh semangat, tidak ada tekanan, tidak cemas, dan berani mengemukakan pendapat. Suasana belajar seperti ini, menurut saya merupakan modal dasar bagi setiap peserta didik untuk tumbuh dan berkembang menjadi pribadi yang mampu beradaptasi, dan menghadapi setiap kemungkinan yang terjadi dan setiap tantangan di era globalisasi ini.
Guru sebagai fasilitator sedikitnya harus memiliki 7(tujuh) sikap, yakni: (1) tidak berlebihan mempertahankan pendapat dan keyakinannya, atau kurang terbuka, (2) dapat lebih mendengarkan peserta didik, terutama tentang aspirasi dan perasannya, (3) mau dan mampu menerima ide peserta didik yang inovatif, dan kreatif, bahkan sulit sekalipun, (4) lebih meningkatkan perhatiannya terhadap hubungan dengan peserta didik seperti halnya terhadap bahan pembelajaran, (5) dapat menerima balikan (feedback), baik yang sifatnya positif, maupun negatif dan menerimanya sebagai pandangan yang konstruktif terhadap diri dan perilakunya, (6) toleransi terhadap kesalahan yang diperbuat peserta didik selama proses pembelajaran, dan (7) menghargai prestasi peserta didik, meskipun biasanya mereka sudah tahu prestasi yang dicapainya (Mulyasa, 2002).

\section{METODE}

Penelitian ini menggunakan metode kualitatif deskriptif. Subjek penelitian ini sebanyak 20 orang guru yang ada di kecamatan Langke Rembong. Teknik pengumpulan data menggunakan wawancara dan angket. Kedua teknik ini akan saling mendukung di mana angket digunakan dengan tujuan menghindari kemungkinan rasa enggan responden dalam memberikan data yang sebenarnya. Instrumen yang digunakan adalah pedoman wawancara dan item angket dalam bentuk terbuka yang dikembangkan dengan mengacu pada fokus masalah yang diteliti. Sebelum analisis data, peneliti melakukan pemeriksaan keabsahan data dengan teknik cek silang. Hal ini bertujuan untuk memastikan bahwa data yang dikumpulkan bersifat akurat. Langkah berikutnya, peneliti melakukan analisis data menggunakan teknik Model Miles dan Huberman (1984: 21 -23). Model analisis data Miles dan Huberman terdiri atas reduksi data, model data, dan penarikan/verifikasi kesimpulan. Reduksi data yang digunakan dalam penelitian ini adalah mengkategorikan data atas data relevan dan data yang tidak relevan dengan fokus penelitian. Data yang tidak relevan diabaikan dalam analisis. Selanjutnya, data yang relevan dengan fokus penelitian disajikan berdasarkan kode-kode yang terdiri atas kode latar/konteks, kode proses, kode aktivitas, kode peristiwa, kode strategi, kode hubungan dan struktur 
Jurnal PG-PAUD Trunojoyo : Jurnal Pendidikan dan Pembelajaran Anak Usia Dini, Volume 6, Nomor 2, Oktober 2019, hal 63-69, ISSN : 2528-3553 (online), ISSN: 2407-4454 (print)

sosial, dan kode naratif (Emzir: 2011: 114123). Kemudian, peneliti menarik kesimpulan secara induktif dari kumpulan data yang telah dipilahkan pada masing-masing kode.

\section{HASIL DAN PEMBAHASAN}

Permendikbud 146 tahun 2014 tentang Kurikulum 2013 Pendidikan Anak Usia Dini menyatakan bahwa Kurikulum 2013 Pendidikan Anak Usia Dini terdiri atas, Kerangka Dasar Kurikulum, Struktur Kurikulum, Pedoman Deteksi DIni Tumbuh Kembang Anak, Pedoman Pengembangan KTSP, Pedoman Pembelajaran, Pedoman Penilaian, dan Buku-Buku Panduan Pendidik. Terkait dengan penelitian ini, peneliti mengkaji kesiapan guru terkait implementasi Kurikulum 2013 (K'13) dalam hal Struktur Kurikulum, Pedoman Deteksi DIni Tumbuh Kembang Anak, Pedoman Pembelajaran, Pedoman Penilaian, dan Buku-buku Panduan Pendidik. Kesiapan guru diukur dari sejauh mana kemampuan guru mengimplementasikan Kurikulum 2013 di PAUD.

Temuan penelitian diuraikan sebagai berikut, pertama terkait dengan struktur kurikulum. Struktur kurikulum sebagaimana dimaksud merupakan pengorganisasian muatan kurikulum seperti kompetensi inti, kompetensi dasar, lama belajar dan program pengasuhan bersama orang tua. Berdasarkan hasil penelitian, para guru yang diteliti telah memuat kompetensi sikap spiritual, sikap sosial, pengetahuan dan kompetensi inti keterampilan dalam Kurikulum Tingkat Satuan Pendidikan. Selanjutnya, dalam mengembangkan kompetensi dasar dan indikator tingkat pencapaian perkembangan anak, para guru merujuk pada KTSP sekolah, permendikbud 137 dan permendikbud 146 tahun 2014. Terkait dengan Indikator tingkat pencapaian perkembangan anak, para guru menyusun indikator tersebut berdasarkan usia peserta didik. Demikian pun dengan lama belajar, dalam menentukan lama belajar, para guru berpatokan pada waktu belajar yang termuat dalam permendikbud 146 tahun 2014. Untuk kelompok usia 4 - 6 tahun, lama belajar paling sedikit 900 menit perminggu. Fakta ini menunjukkan bahwa para guru memiliki pemahaman yang cukup terkait kompetensi inti, kompetensi dasar, indikator yang harus dikembangkan oleh peserta didik dan lama belajar sesuai kelompok usia serta mengetahui dokumen yang dapat dijadikan referensi atau rujukan. Pengetahuan awal ini sangat penting bagi guru mengingat proses pembelajaran dan target-target pembelajaran anak usia dini mesti dilakukan secara sistematis dan berpatokan pada pedoman yang berlaku. Sementara itu, dalam kaitannya dengan program pengasuhan bersama orang tua, jawaban guru cukup bervariasi. Hal ini menunjukkan bahwa program pengasuhan bersama orang tua tampaknya belum menjadi program yang dilaksanakan oleh banyak TK/PAUD. Padahal, Kurikulum 2013 juga mendorong agar guru dan orang tua menjalin kerjasama dalam mengasuh dan mengembangkan potensi diri anak.

Kedua, Deteksi Dini Tumbuh Kembang Anak (DDTK). DDTK juga menjadi bagian yang penting dalam implementasi Kurikulum 2013 di PAUD. Dari hasil penelitian, para guru menganggap bahwa deteksi dini tumbuh kembang AUD perlu dilakukan. Alasannya DDTK diperlukan untuk mengetahui perkembangan anak dan mengetahui tingkat pertumbuhan dan perkembangan anak berjalan normal atau tidak. Pentingnya DDTK tidak sekadar asumsi atau pendapat saja, para guru juga telah melakukan DDTK. DDTK dilakukan melalui pengamatan atau wawancara orang tua. Beberapa guru melakukan DDTK secara bertahap mulai dari pengamatan di kelas, kemudian wawancara orang tua bahkan melibatkan pihak lain seperti dinas kesehatan untuk memeriksakan kesehatan maupun perkembangan anak. DDTK yang dilakukan oleh para guru terkait pertumbuhan dan perkembangan anak. Berkaitan dengan pertumbuhan, para guru melakukan pengukuran terhadap berat badan dan tinggi badan. Sementara dalam mengukur pertumbuhan lingkar kepala, pertumbuhan gigi dan tulang, guru melibatkan pihak puskesmas dan dinas kesehatan. Berkaitan dengan perkembangan anak, guru telah melakukan deteksi dini terhadap aspek perkembangan Nilai agama dan moral, sosial emosional, kognitif, bahasa, seni dan kreativitas dan fisik motorik anak. Hasil deteksi dini tumbuh kembang anak digunakan oleh guru untuk memberikan stimulus. Jika ada masalah terkait dengan pertumbuhan anak, guru segera mengkomunikasikannya ke dokter atau ahli kesehatan. Prosedur dan pelaksanaan DDTK ini menunjukkan bahwa para guru telah 
68 Jurnal PG-PAUD Trunojoyo : Jurnal Pendidikan dan Pembelajaran Anak Usia Dini, Volume 6, Nomor 2, Oktober 2019, hal 63-69, ISSN : 2528-3553 (online), ISSN: 2407-4454 (print)

melakukan DDTK sesuai dengan pedoman penyelenggaraan Kurikulum 2013 dalam permendikbud 146 tahun 2014.

$$
\text { Ketiga, Pembelajaran. Dalam }
$$

melaksanakan proses pembelajaran, para guru menerapkan pendekatan saintifik dengan model pembelajaran sentra dan kelompok. Dalam kegiatan pembukaan para guru menyapa anak, menanyakan kabar anak, berdoa, presensi dan menyampaikan tema/subtema pembelajaran dalam satu hari. Namun, dalam kegiatan inti, pendekatan saintifik yang meliputi kegiatan mengamati, menanya, mengumpulkan informasi, menalar, dan mengkomunikasikan belum tampak. Sebagian besar guru mengisi kegiatan inti pembelajaran hanya dengan kegiatan menggambar, mewarnai, bercerita atau bermain peran. Hal ini dikuatkan dengan fakta terkait metode pembelajaran yang digunakan guru. Metode pembelajaran yang paling banyak digunakan guru antara lain bercerita, bercakap-cakap, pemberian tugas, dan sosiadrama/bermain peran. Tidak ada guru yang menerapkan metode karya wisata, proyek atau eksperimen. Jika ditinjau dari fasilitas yang disediakan sekolah, menurut para guru, sekolah telah menyediakan fasilitas yang memadai. Boleh jadi ketersediaan fasilitas yang cukup itu sesuai dengan metode pembelajaran yang sering digunakan guru. Dalam pembelajaran, guru juga melibatkan orang tua terutama ketika melaksanakan kegiatan pentas seni. Sementara itu, dalam kegiatan penutup guru memberikan penguatan pada anak tentang materi hari itu, tanya jawab, bercerita, menyebutkan janji pulang sekolah dan berdoa.

Keempat, Penilaian. Dalam melakukan penilaian perkembangan anak, guru sering menggunakan teknik penilaian berupa skala capaian perkembangan, catatan hasil karya dan checklist. Para guru melakukan penilaian terhadap peserta didik dengan tujuan, mendapatkan informasi tentang pertumbuhan dan perkembangan anak. Pemahaman guru terkait tujuan penilaian ini masih perlu dikuatkan. Dalam permendikbud 146 tahun 2014 dinyatakan bahwa selain untuk mendapatkan informasi tentang pertumbuhan dan perkembangan anak, penilaian juga bertujuan untuk menggunakan informasi yang didapat sebagai masukan untuk merancang program pembelajaran, memberikan informasi kepada orang tua dan memberikan bahan masukan kepada stakeholder pendidikan. Kenyataan pemahaman guru terkait tujuan penilaian dapat menunjukkan bahwa pembelajaran yang dilaksanakan guru masih berfokus pada hasil bukan proses.

Dalam melakukan penilaian, sebagian guru kesulitan melakukan rekapitulasi perkembangan anak. Hal ini disebabkan karena guru hanya mengetahui instrument penilaian harian. Pemahaman guru terkait melakukan kompilasi penilaian harian, mingguan dan bulanan masih rendah.

Hasil penilaian guru terhadap anak selalu dilaporkan kepada orang tua. Dalam satu semester guru melaporkan hasil penilaian anak kepada orang tua sebanyak satu kali. Namun, dapat dibayangkan bila kemampuan guru dalam melakukan kompilasi penilaian anak masih rendah. Laporan perkembangan yang disampaikan kepada orang tua dapat saja hanya didasarkan pada potongan fakta yang belum tentu akurat.

Kelima. Kepemilikan buku pedoman/panduan implementasi Kurikum 2013. Para guru memiliki buku pedoman/panduan implementasi Kurikulum 2013. Pedoman yang dimiliki guru berupa permendikbud 137 dan 146 tahun 2014 dan buku pedoman Kurikulum 2013 yang diterbitkan pemerintah.

Berdasarkan temuan terkait lima hal dalam penyelenggaraan Kurikulum 2013 di PAUD tampak bahwa secara administratif para guru PAUD sudah siap melaksanakan Kurikulum 2013 di PAUD. Namun, secara praktis para guru masih mengalami kesulitan. Kesulitan tersebut terkait dengan penerapan pendekatan saintifik dan pelaksanaan penilaian otentik. Dalam pembelajaran, para guru kesulitan merancang tema dan materi kegiatan yang mendorong anak melakukan kegiatan mengamati, menanya, mengumpulkan informasi, menalar, dan mengkomunikasikan. Itu sebabnya, pembelajaran lebih banyak diarahkan pada kegiatan menggambar dan mewarnai. Dalam melakukan penilaian, guru kesulitan melakukan kompilasi data hasil penilaian harian dan menyusun laporan perkembangan anak. Kesulitan ini terjadi karena sebagian besar guru berkualifikasi SMA/SMK dan S-1 non PAUD.

\section{SIMPULAN}

Penyelenggaraan Kurikulum 2013 di PAUD ternyata tidak mudah. Implementasi $\mathrm{K}$ 
Jurnal PG-PAUD Trunojoyo : Jurnal Pendidikan dan Pembelajaran Anak Usia Dini, Volume 6, Nomor 2, Oktober 2019, hal 63-69, ISSN : 2528-3553 (online), ISSN: 2407-4454 (print)

13 di PAUD perlu diimbangi dengan kompetensi tenaga pendidik yang memadai. Penelitian ini telah menunjukkan bahwa secara administratif, guru PAUD sudah siap melaksanakan Kurikulum 2013. Namun, secara praktis para guru masih mengalami kesulitan. Kesulitan tersebut terkait dengan penerapan pendekatan saintifik dan pelaksanaan penilaian otentik. Dalam pembelajaran, para guru kesulitan merancang tema dan materi kegiatan yang mendorong anak melakukan kegiatan mengamati, menanya, mengumpulkan informasi, menalar, dan mengkomunikasikan. Itu sebabnya, pembelajaran lebih banyak diarahkan pada kegiatan menggambar dan mewarnai. Dalam melakukan penilaian, guru kesulitan melakukan kompilasi data hasil penilaian harian dan menyusun laporan perkembangan anak. Kesulitan ini terjadi karena sebagian besar guru berkualifikasi SMA/SMK dan S-1 non PAUD.

Berdasarkan temuan ini, diperlukan peningkatan kompetensi guru melalui berbagai pelatihan di bidang pengembangan Kurikulum 2013. Pelatihan tidak saja berfokus pada pengembangan perangkat pembelajaran berbasis K 13 melainkan juga lebih diarahkan pada praktik pengajaran di kelas (microteaching).

\section{DAFTAR PUSTAKA}

Alma, Buchari, dkk. 2013. Guru profesional Menguasai Metode dan Terampil Mengajar. Bandung: Alfabeta.

Ansyar, Mohamad. (2015). Kurikulum Hakikat, Fondasi, Desain, dan Pengembangan.Jakarta: Kencana Prenadamedia Group.

De Gomes, F., Rahmat, Stephanus T., dan Palmin, B. 2018. "Evaluasi Kelompok Bermain dan Taman Kanak-kanak di Kabupaten Manggarai Berdasarkan Norma, Standar, Prosedur, dan Kriteria Menurut Dirjen Dikti”. Artikel Penelitian [Belum Dipublikasikan]. Ruteng: STKIP Santu Paulus.

Emzir. 2011. Metodologi Penelitian Kualitatif Analisis Data. Cet. ke-2. Jakarta:PT

RajaGrafindo Persada.
Idi, Abdullah, dkk. (2014). Pengembangan Kurikulum Teori dan Praktik. Depok:PT Rajagrafindo Persada.

Majir, Abdul. (2016). Pengembangan Kurikulum Pengajaran dan Pembelajaran Teori dan Model. Jakarta: CV Infomedika.

Mardalis. (2010). Metode Penelitian Suatu Pendekatan Proposal Jakarta:Bumi Aksara.

Miles, Matthew B \& Huberman, A. Michael. 1984. Qualitative Data Analysis: A Sourcebook of New Method. London: Sage Publications.

Payong, Marselus. (2011). Sertifikasi Profesi Guru Konsep Dasar, Problematika, dan Implementasinya. Jakarta: PT Indeks

Sennen, Eliterius, dkk. (2016). Pedoman Penulisan Karya Ilmiah. Ruteng: STKIP Santu Paulus Ruteng. 